\title{
Determinants of Financial Sustainability of Rural Banks in Ghana
}

\author{
Joyce Ama Quartey (Corresponding author) \\ Christian Service University College \\ Department of Accounting and Finance \\ PO Box 3110 Kumasi, Ghana
}

Tel: 233-244-733-807Ｅ-mail: jquartey@csuc.edu.gh

\author{
Okyere Darko Desmond \\ Christian Service University College \\ Department of Accounting and Finance \\ PO Box 3110 Kumasi, Ghana
}

Tel: 233-244-733-807

\begin{abstract}
Joseph Yensu
Institute of Entrepreneurship and Enterprise Development

Kumasi Technical University, Kumasi, Ghana
\end{abstract}

Tel: 233-545-707-171

Received: January 8, 2019

Accepted: March1, 2019

Published: March 4, 2019

doi:10.5296/ijafr.v9i1.14196

URL: https://doi.org/10.5296/ijafr.v9i1.14196

\begin{abstract}
Rural banks play enormous role in ensuring socio-economic development in Ghana. However, it has been observed that these rural banks face a number of challenges that affect their sustainability. This study examined the determinants of financial sustainability of the Rural Banks in Ghana. The cross- sectional survey was used where questionnaires were designed to
\end{abstract}


collect data. The selections of the respondents were done using the snow ball sampling procedures to locate the 150 customers of three rural banks. The results from the multiple regression analysis showed that the amount of loans significantly affect the financial sustainability of the Rural Banks. The findings further showed that a unit increase in loan interest would lead to 20.5 percent reduction in the number of years a customer had been with the bank thereby affecting their financial sustainability. It was obvious from the study that loans and advances were not in the best of quality. Since these have bearing on the sustainability of the banks, it is recommended that management of these banks put in place rigorous strategies to improve the credit appraisal systems and boost loan recovery.

Keywords: Financial sustainability, Determinants, Rural Banks, Loans, Ghana

\section{Introduction}

The ultimate aim of every government is to improve the living conditions of its citizens especially, the poor and vulnerable. Improving people's livelihood is seen as one of the areas for achieving the Sustainable Development Goals (SDGs). The Ghana Statistical Service (2018) puts the poverty status of the country's population at about 23.4 percent. This is made up of about 39.5 percent in rural areas.

The banking sector in Ghana remains one of the most profitable sectors regardless of the increasing competition. The principal objective for the existence of banks especially, rural banks is to bring banking services to the rural people and to encourage the habit of savings. In their efforts to achieve their objectives, the banks are exposed to a number of factors which affect their sustainability (Antwi and Apau, 2015). Price Waterhouse Coopers conducted a survey in Ghanain 2010 on the financial sustainability of rural banks, and the result shows that bank'sprofitbefore tax declined from 30.4 percent in 2007 to 19.7 percent in 2009 (Mills and Amowine, 2013). They explained that the rapid declining of banks' loans portfolio has negative effects on profit margins. The impairment charges for non-performing loans increased over the three year period, from $\mathrm{GH} \phi 60$ million in 2007 to $\mathrm{GH} \phi 266$ million in 2009 (Mills and Amowine, 2013, p, 507).

Most banks were not able to recover cost from their operations and they are described as the loss making group with sustainability challenges. Though rural banks constitute about 50 percent ofthe total banking outlets in Ghana (IFAD, 2008), their performance in deposits mobilization, loans and total assets is low (Afriyie, 2013). The proportion of total deposits mobilized by RCBs averaged only between four percent and seven percent for loans and six percent for total asset (Aboagye and Otieku, 2010). This performance according to Afriyie and Akotey (2013) is very low. A survey conducted by the Bank of Ghana in 2009 also showed that the financial performance of 17 out of the 133 rural and commercial banks were not encouraging. Among the 17 averaged performance rural banks in Ghana, six experienced negative net worth (Nair and Fissha,2010).In addition, Aboagye and Otieku (2010) conducted a similar study of 30 rural banks in Ghana and the result was that almost all the rural banks were either satisfactory performers $(44 \%)$ or fairly performers $(50 \%)$. This indicates that the sustainability of rural banks in Ghana is threatening (Owusu-Antwi et al., 2014). It is noteworthy therefore, that the poor financial performance of some rural banks led to the 
collapse of 23 rural banks as at June, 2007 (Afriyie \& Akotey 2013).

More than half of the population lives in the rural areas in Ghana do not have access to credit facilities and the demand for financial services far exceeds the currently available supply (Asiama and Osei, 2007). This raises the question of what ought to be done to ensure the continuous provision of credits to the poor by rural banks. Effort to answer this question has led to several studies conducted on financial performance of banks in Ghana (AddaeKorankye, 2014; Sebe-Yeboah and Mensah, 2014; Abdul-Baaki and Bunyaminu, 2013; Aboagye and Otieku, 2010; Afriyie and Akotey, 2013; Asante and Tengey, 2014; Donkor, 2013; Owusu-Antwi et al., 2014). This study however, employs multiple regression analysis in assessing the determinants of financial sustainability of rural banks and also analyzes the customer views of financial sustainability of the rural banks.

\section{Literature Review}

Rural banking in Ghana takes its origin from the early 1970s (Asiedu -Mante, 2011). Before the late 1970s, rural dwellers (more especially, farmers) in Ghana had less access to financial services for farm and non-farm activities.

Sustainability is defined within the context of two key words "permanence" (Navajas et al, (2000) and "performance appraisal" (Schreiner, 2000). Permanence means that, rural banks should be capable or have the ability to remain in business for a longer period of time. Performance appraisal on the other hand, means that rural banks must have the ability to perform its functions on a continuous or sustainable basis). These two words are interrelated.

Khandker and Khalily (1995) defined sustainability as the capacity of an institution to constantly carry out its activities to achieve stated objectives. Woller et al. (1999) also defined sustainability as the capacity of an institution to produce outputs that meet the public (customers') satisfaction and that the institution receives enough resources and input to continueproduction. Woolcock (1999) viewed sustainability as a program's capacity to remain financially sound in the absence of subsidies or foreign support. Woolcock's definition of sustainability explains the financial self-sufficiency of an institution to remain in a business.

The diagram below explains the factors that affect the financial sustainability of Rural Banksin Ghana. In this study, sustainability is defined as the capacity and capability of an institution to become financially viable (ability to raise more income to cover its expenditure) by recruiting and deploying qualified personnel, and encouraging them through motivation to achieve the institutional objectives and at the same time win customers' loyalty by meeting their satisfaction. 


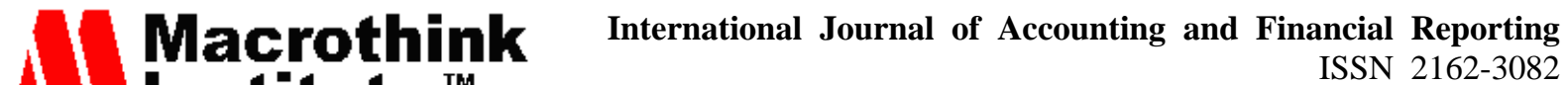 2019, Vol. 9, No. 1}

2.1 Hypotheses Development

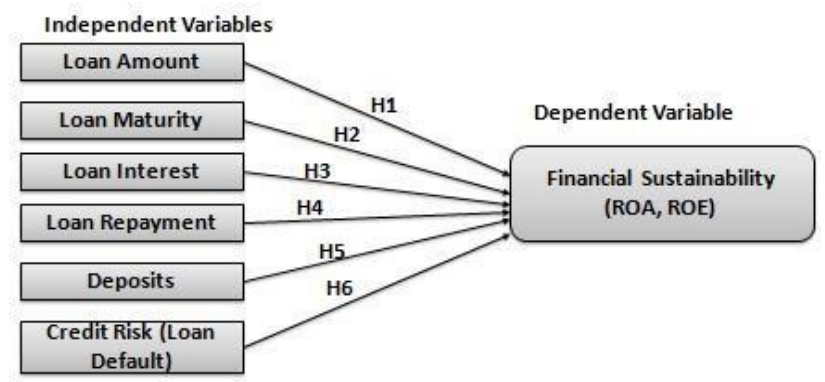

Figure 1. Conceptual framework on factors affecting financial sustainability ofbanks

The factors include loan amount, loan maturity, loan interest, loan repayment rate, coverage of customers and credit risks (Littlefield et al., 2003; Honohan, 2004). These factors form the independent variables for the study. The financial sustainability or performance is measured using the Return on Assets (ROA). This ratio formed the dependent variable for the study. The multiple regression analysis was used to assess the effects of the independent variables on the dependent variable.

\subsubsection{Loan Amount and Portfolio}

The amount of loan a bank can give to its clients and the ability to collect it determines its capacity to make profit. It is therefore advisable for banks to increase its loan amount to its clients so that much profit (in the form of interest) can be accrued to make them financially sustainable. Nyamsogoro (2010) suggested that financial institutions can increase the size of loans or increase the number of customers for the loans or combine the two strategies. Therefore, the hypothesis below was formulated:

Hypothesis 1:

Null Hypothesis $\left(\mathrm{H}_{\mathrm{O}}\right)$ : There is no effect of loan amount on financial sustainability of Rural Banks.

Alternative Hypothesis $\left(\mathrm{H}_{1}\right)$ : There is an effect of loan amount on financial sustainability ofRural Banks.

\subsubsection{Maturity of Loans}

For a bank to increase the loan size Schreiner (2001) suggested the following; term to maturity, dollars per instalment, time between instalments and number of instalments, and average balance. These are the areas a bank should consider before increasing the size of loans. Maturity of loans is the difference in time of loan allocated to customers' and the date for repayment of the loan. Nyamsogoro (2010) observed it as the remaining time for the loan to meet deadline. It is argued that the time allocated for loan payment determines the financial sustainability of banks (Brake, 2000 and Schreiner, 2001).

According to Brake (2000), the risk associated with longer maturity of loan is very critical to affect the financial performance of banks. In contrast, Schreiner (2001) argued that longer 
maturity of loans indicates greater profitability of banks but lead to less coverage. What the two researchers are portraying is that banks need to be careful in determining loan maturity. If the bank wants to increase the number of borrowers then it is better to decrease the loan maturity. On the other hand, if the bank wishes to reduce the number of borrowers and increase more profit then it is better to increase the loan maturity. The two approaches determine the financial sustainability of banks. However, this depends on the interest rates.

The loan size can also be explained as the dollars per installment which affects the profitability of banks. The large loan size means more interest profit would be accrued. It also means the maximum possible loss due to default (Nyamsogoro, 2010). The large loan size lowers average cost of loan disbursement, as their costs are mostly fixed. Thus, longer loan maturity would imply higher per-dollar variable costs because lenders take care due to greater risk exposure (Schreiner, 2001). The average balance also measures the level of resources held in terms of loan, without consideration for length of the term to maturity.

It is argued that loans with large average balances are more profitable (Schreiner, 2001). Again, time between installments may affect the profitability of banks. The more the loan payment installment increases the more the bank stands at risk since the borrower can default (Schreiner, 2001). However, Armendáriz and Morduch (2007) argued that frequent loan installment can lead to profitability of banks. If this is done, then high repayment rates can be achieved which will in turn, reduce default. Thus the study intended to find a solution to the second hypothesis below:

Hypothesis 2:

Null Hypothesis $\left(\mathrm{H}_{\mathrm{O}}\right)$ : There is no effect of loan maturity on financial sustainability of Rural Banks.

Alternative Hypothesis $\left(\mathrm{H}_{2}\right)$ : There is statistically significant effect of loans maturity on financial sustainability of Rural Banks.

\subsubsection{Interest Rate/Amount}

The loan interest given by the banks to their clients may determine the amount of income they get. It is one of the main sources of income to the banking institutions. The ability of the banks of gets back more profit (loan interest). Thus, according to Armendáriz and Morduch (2007), the financial sustainability of banks depends on the capacity of the institution to grant more loans to people at an interest rate to cover all its costs (Shankar, 2007). It is argued that high interest rates on loans positively correlate with the profitability of the bank which can sustain them in the business environment.

However, from the economic point of view, the larger the interest rate, the less interest clients develop in obtaining such loans unless under a critical condition. Thus, when clients fail to obtain loans because of the high interest rates, it will negatively affect the profit of the bank (Nyamsogoro, 2010). To reconcile this, Armendáriz and Morduch (2007) suggested that interest rate on loans must be incentive in itself. Being incentive means that the interest should be less than what the borrower will get from investing the borrowed sum from the 


\section{Ml Macrothink}

International Journal of Accounting and Financial Reporting

ISSN 2162-3082

2019, Vol. 9, No. 1

banks. The borrower will get financial or non-financial benefits from the loan amount invested. This will encourage the borrower to go in for loan from the banks. The method to determine the levels of interest on loans to make it incentive- packaged depends on the type of technique that would be used by the banks. Therefore the study formulated the third hypothesis as:

Hypothesis 3:

Null Hypothesis $\left(\mathrm{H}_{\mathrm{O}}\right)$ : There is no effect of interest rates on financial sustainability of Rural Banks.

Alternative Hypothesis $\left(\mathrm{H}_{3}\right)$ : There is statistically significant effect of interest rates on financial sustainability of Rural Banks.

\subsubsection{Loan Repayment Rate}

The financial sustainability or profitability of banks is also dependent on the degree of loan repayment rate (Schreiner, 2001). Nyamsogoro (2010) argued that higher interest rate and loan amount are not sufficient to have determined the financial sustainability of banks if the loan repayment rate is very low. Thus, the financial performance of banks can be determined by combining the interest rates, and the loan amount together with high repayment rate. High repayment rate depends on the capacity of the bank to collect the loans from its clients (Schreiner, 2000).

This implies that a less efficient bank, unable to effectively collect its loans from customers will stand the risk of default thereby affecting its financial performance. The inefficiency of banks to collect loans led to bad loans, meaning that the client cannot fully pay the loan in addition to the interest (Awunyo-Vitor, 2013). Thus, instead of profit being earned, financial loss is encountered leading to adverse effects on the profitability of banks. Another effect of bad loans on banks can be seen in their lending capacity. Studies from Awunyo-Vitor (2012) and Chelagat (2012) showed that bad loans reduce bank's capacity to lend. It calls for a solution to the forth hypothesis formulated as:

Hypothesis 4:

Null Hypothesis $\left(\mathrm{H}_{\mathrm{O}}\right)$ : There is no effect of loan repayment rate on financial sustainability of Rural Banks.

Alternative Hypothesis $\left(\mathrm{H}_{4}\right)$ : There is statistically significant effect of loan repayment rate on financial sustainability of Rural Banks.

\subsubsection{Coverage of Customers (Deposits)}

The sustainability of any financial institution depends on the coverage (number of customers) or amount of deposits from customers. Coverage is simply defined as the number of customers served by a particular financial institution (Rai, 2011) or the number of people served but who were not served previously (Meyer, 2002). It is assumed that the capacity of banks to win more customers to enjoy their services, the better the coverage or outreach (Nyamsogoro, 2010). It is argued that the larger the number of clients or borrowers, the more 
the bank becomes sustainable (LOGOTRI, 2006). This is because of the fact that the customers will eventually make deposits into the accounts of the banks.

The sustainability of banks is determined by many factors which have been stated above (Adongo and Stork, 2005). Navajas, et al., (2000) in their study established a link between the number of clients a bank may have and its sustainability.They explained that coverage may bring about sustainability while the sustainability may enhance coverage. Nyamsogoro (2010) added that factors such as the size and structure of a particular bank and their products or services may influence customers or help to win more clients and expand coverage and invariably affect profitability. Thus, a larger customer base of any financial institution (coverage) becomes a useful tool in determining its financial sustainability. Thus the fifth hypothesis was formulated as:

Hypothesis 5:

Null Hypothesis $\left(\mathrm{H}_{\mathrm{O}}\right)$ : There is no effect of coverage of customers (deposits) on financial sustainability of Rural Banks.

Alternative Hypothesis $\left(\mathrm{H}_{5}\right)$ : There is statistically significant effect of coverage of customers (deposits) on financial sustainability of Rural Banks.

\subsubsection{Credit Risks Factors (Loan Default)}

Rufai (2013) conducted a study to assess the effectiveness of credit risk management on the performance of financial institutions in Nigeria. The study revealed that credit risk affect the financial performance of Credit Unions in Nigeria. This therefore requires financial institutions to maintain high interest income and give attention to credit risk mitigation measures. Soyemiet al., (2014) assessed the risk management practices of banks in Nigeria using financial statements to calculate ROA and ROE. The study used multiple regression analysis and the result showed that credit risk and credit risk management affect profitability. They showed that credit risk management practices such as credit, liquidity, operating and capital risk practices affected profitability of the bank.

Adeusi et al. (2013) examined the relationship between credit risks and profitability of financial institutions in Nigeria. Data was collected from the financial institutions. The multiple regression analysis was used and the result showed that credit risks reduce the profitability of financial institutions. The study again showed that credit risk management reduced the occurrence of credit risk and improved financial performance. The study found a significant relationship between banks performance and risk management. Poudel (2012) assessed the effects of credit risks and credit risk management on profitability of 31 financial institutions in Nepal from 2001 to 2011. The study compared the profitability ratio to default rate, cost of per loan assets and capital adequacy ratio where descriptive, correlation and regression was used to analyze the data. The study revealed that all these parameters have an inverse impact on banks' financial performance; however, the default rate is the most predictor of bank financial performance.

Addae-Korankye (2014) conducted a study on loan default and financial performance of 
financial institutions in Ghana. The study found the causes of loan default to include; high interest rate, inadequate loan sizes, poor appraisal, lack of monitoring, and improper client selection. Measures to control default were found to include training before and after disbursement, reasonable interest rate, monitoring of clients, and proper loan appraisal.

The study also found that loan default affects the profitability of financial institutions. Therefore the sixth hypothesis needed a solution was formulated as:

Hypothesis 6:

Null Hypothesis $\left(\mathrm{H}_{\mathrm{O}}\right)$ : There is no effect of credit risk on financial sustainability of Rural Banks.

Alternative Hypothesis $\left(\mathrm{H}_{6}\right)$ : There is statistically significant effect of credit risk on financial sustainability of Rural Banks.

\section{Data and Methodology}

Research design according to Churchill and Iacobucci (2005) is the structure used in research to collect and analyze data. The study used the survey research as the research design. Researchers use two main types of survey research namely the cross-sectional survey and the longitudinal survey. The cross-sectional survey design was used in this study because it does not involve much time. Furthermore, the cross-sectional survey was selected as the research design in this study, since according to Hair et al (2006) it is an important tool used to perform statistical analysis such as multiple regression and Analysis of Variance (ANOVA). Cross-sectional survey also allows researchers to collect large amount of data from a given population (Creswell, 2011). This study covers three Rural Banks in Ghana. These banks included in the study are located in the Ashanti Region of Ghana. The three banks used in the study have been in the banking business for quite a longer period of time.

\subsection{Sample Selection and Data}

The population of the study was the customers of the three Rural Banks in Ghana. It also comprise of the number of workers in the Rural Banks. Customers to the institutions comprise of those who save there and make other transactions in the name of the bank. Hence group loan clients, individual and small and medium enterprise (SME) loan clients made up the population. The population of customers for the three banks was about 20,000 in Kumasi while the workers constituted about 200 staff. The staff is composed of the credit officer, the branch manager, the loan manager and cashiers among others. A sample was used in this study to generalize the lists of customers who have conducted business with the three Rural Banks for more than five years. This was done because it is argued that the more the number of years of transacting business with the bank, the more customers becomes aware of most of the bank's policy. The study used both the probability and non-probability sampling to select respondents. The probability sampling used for the study is the simple random sampling. The non-probability sampling is the purposive sampling. From the list, the random sampling method was used to select 50 customers from each of the lists provided by the Rural Banks. In all, 150 customers were selected from the three Rural Banks. The purposive sampling 
method was used to select the branch managers' of the three Rural Banks and credit officers for interview. The study considered these respondents because the researchers believed they have the knowledge concerning the subject matter and that they can provide relevant information.

\subsection{Statistical Analysis}

A regression describes and evaluates the relationships between a given dependent variable and one or more independent variables. It is assume that regression is an appropriate statistical method in order to confirm or disconfirm the chosen hypotheses. Regression analysis is used to test the established hypotheses. The multiple regression analysis was conducted to assess the determinants of financial sustainability of the rural banks. The dependent variable used in this study was the ROA. The independent variables include the credit risk factors (loan default/NPLS), loan amount, loan maturity, loan interest, loan repayment and coverage (number of customers). The general theoretical model for the regression analysis is presented as

$$
Y=\beta_{0}+\beta_{1} X_{1}+\beta_{2} X_{2}+\beta_{3} X_{3}+\ldots+\beta_{n} X_{n}+u
$$

Where:

$\mathrm{Y}$ is the dependent variable

$\mathrm{X}$ is the independent variables

$\beta_{1}-\beta_{n}$ are the coefficients of the independent variables

$\beta_{0}$ is the intercept

$u$ represents other factors.

The mean scores of response on the five-point Likert scale for each of the Likert item was calculated. The standard deviation was also calculated to show the deviation of the responses on the Likert items. The value of the mean score determines the Likert Scale (Strongly Disagree, Disagree, Slightly Agree, Agree and Strongly Agree). The mean shows the average response from the respondents while the standard deviation shows the level of disparity of the response from the mean. The wider that the difference of the mean and the standard deviation, the greater the variation in the responses. The reverse is true when the difference is minimal or insignificant.

\section{Research Results and Discussions}

\subsection{Regression Results}

The multiple regression analysis was performed to assess the impact of the independent variables (loans, loan interest, loan maturity, customer deposits, loan overdue and loan repayment amount) on the dependent variable (Return on Asset). In the model summary results (Table 1), the R-Square (.527) and Adjusted R-Square (.325) imply that the independent variables explain 52.7 percent and 32.5 percent of variations in the profitability (ROA) of the banks taking other factors into consideration. The Adjusted R-Square value of 


\section{Mll Macrothink}

International Journal of Accounting and Financial Reporting

ISSN 2162-3082

2019, Vol. 9, No. 1

0.325 showed that 32.5 percent of the variations in ROA of the banks are by the amount of loans given to customers.

Table 1. Model summary explaining variation of the independent variables and ROA

\begin{tabular}{lllll}
\hline Model & $\mathrm{R}$ & R Square & Adjusted R Square & Std. Error of the Estimate \\
\hline 1 & 0.726 & 0.527 & 0.325 & 1572748.6253193 \\
\hline
\end{tabular}

a. Predictors: (Constant), Loan Maturity, Loan Interest, Customer Deposit, Loan Overdue (Loan Default), Loans, Repayment Amount

b. Dependent Variable: ROA

The R-Square value is moderate using the rule of thumb that the $\operatorname{Adj}^{2} \leq 0.20$ is classified as very weak; $0.20<\mathrm{Adj}^{2} \leq 0.40$ is classified as weak; $0.40<\mathrm{Adj} \mathrm{R}^{2} \leq 0.60$ is classified as reasonable or moderate; $0.60<\mathrm{Adj}^{2} \leq 0.80$ is classified as strong; and $\operatorname{Adj}^{2}>0.80$ is classified as very strong. As indicated in Table 2, the probability of the F- statistic value of 21.603 means that the result of the regression model is significantly better prediction of ROA than using the mean value of ROA.

Table 2. Analysis of Variance (ANOVA) from the multiple regression analysis

\begin{tabular}{llllll}
\hline Model & Sum of Squares & df & Mean Square & F & Sig. \\
\hline Regression & 38634615235826.57 & 6 & 6439102539304.42 & 21.603 & $0.045^{\text {b }}$ \\
\hline & 34629535338214.10 & 14 & 2473538238443.86 & & \\
\hline 1 Residual & 73264150574040.67 & 20 & & & \\
\hline
\end{tabular}

a. Dependent Variable: ROA

b. Predictors: (Constant), Loan Maturity, Loan Interest, Customer Deposit, Loan Overdue (Loan Default), Loans, Repayment, Amount.

The F-statistic for the overall regression relationship was significant at 0.045 . This probability value of 0.045 is less than the alpha value of 0.05 . This suggests that the null hypothesis which indicated that there is no relationship between ROA and loans, loan interest, loan maturity, customer deposits, loan overdue and loan repayment amount was rejected. From Table 3, the regression coefficient shows that it was loan amount and loan default which showed significant impact on profitability of the banks. The beta coefficient of $0.521 \mathrm{implies}$ that loan disbursement by the banks made the strongest unique contribution to 
explaining profitability when all other variables in the model are controlled for.

Table 3.Regression coefficient of variables from the regression results that explain profit (ROA)

\begin{tabular}{llllll}
\hline Model & $\begin{array}{l}\text { Unstandardized } \\
\text { Coefficients }\end{array}$ & Standardized & $\mathrm{t}$ & Sig. & Coefficients \\
& $\mathrm{B}$ & Std. Error & Beta & & \\
\hline (Constant) & 2318015.319 & 2129999.949 & & 1.088 & 0.295 \\
\hline Loans & -0.153 & 0.077 & 0.521 & -1.982 & 0.038 \\
\hline Loan Interest & -0.065 & 0.202 & -0.81 & -0.321 & 0.753 \\
\hline Customer Deposit & 0.065 & 0.042 & 0.642 & 1.566 & 0.140 \\
\hline Repayment Amount & 0.575 & 0.644 & 0.344 & 0.892 & 0.387 \\
\hline $\begin{array}{l}\text { Loan Overdue (Loan } \\
\text { Default) }\end{array}$ & -0.715 & 5.022 & -0.035 & -0.142 & 0.049 \\
\hline \begin{tabular}{l} 
Loan Maturity \\
\hline
\end{tabular} & -2235.794 & 4246.212 & -0.098 & -0.527 & 0.607 \\
\hline
\end{tabular}

The remaining independent variables such as loan maturity, loan interest, loan repayment amount and customer deposits were not statistically significant to profit (ROA) of the banks. That is, the significant values exceeded the alpha value of 0.005 . This implies that there was not much evidence to prove that those variables have significant impact on the bank's profitability. As indicated in Table 4.3, the standardized beta coefficient value of 0.521 shows that, holding all other variables constant, a unit increase in the amount of loans the banks willbe willing to grant to their customers is likely to increase income (profitability) by 51 percent.Also, the standardized beta coefficient value of -.035 shows that, holding all other variables constant, a unit increase in loan default by the customers of the banks will lead to 3.8 percent reduction in profitability.

\section{Recommendations and Conclusions}

\subsection{Recommendations}

It was obvious from the study that loans and advances were not in the best of quality. The study recommends two approaches for the improvement of loan quality. The first approach has to do with the loan granting process where the study recommends that the credit appraisal team must take the necessary pains at selecting beneficiaries for loans. Only clients who have a proving ability to manage their businesses profitably should be considered for facilities 


\section{Ml Macrothink}

International Journal of Accounting and Financial Reporting

ISSN 2162-3082

2019, Vol. 9, No. 1

from the bank. The second approach has to do with a rigorous programme to boost recoveries. The study found a decrease in loan interest of the banks in some of the years under consideration. This may be attributed to default of loans from some of the customers. The study recommends that management should employ fresh team on contract basis purposely for loan recoveries and the team should be given targets and achievements of which would earn them a renewal of their employment contracts. The study further recommends that top management should be thickly involved in loan appraisal and loan recovery.

The study discovered that in some instance, advances were growing faster than deposits. This if not checked has an adverse impact on financial sustainability. Management must at all times be conscious that they are not under any obligation to grant loans to customers but they arealways under obligation to pay back customer's deposit. To this end, management is encouraged to resist undue pressure from customers for loans which tend to affect their liquidity. Illiquidity is a threat to the sustainability of any financial institution. Management must always be guided by the fact that it is far simpler to grant loans than to recover them. Performance contract should be signed by every staff especially with regards to deposits mobilization and earnings or bonuses to staff should be based on performance. Star performance should be copiously rewarded to encourage them to perform more and also for others to emulate.

\subsection{Conclusion}

The multiple regression analysis was done to assess the factors affecting the financial sustainability of the banks. The ROA was used as the dependent variable while customer deposits, loan amount, interest, repayment amount, loan overdue and loan maturity were independent variables. The result was that loan amount and loan overdue were significant factors. This means that loan amount and loan overdue significantly determined the financial sustainability (ROA) of the banks. The more the banks grant loans to their customers, the more profit they are able to make. This was because of the ability of the banks to collect large loan repayment for the period.

\section{References}

Abdul-Baaki, Y. K., \& Bunyaminu, A. (2013). Assessing Rural Banks Effectiveness in Ghana. International Business Research, 6(3), 21-35.

Aboagye, A. Q., \& Otieku, J. (2010). Are Ghanaian MFIs' Performance Associated with Corporate Governance?. Corporate Governance, 10(3), 307-320.

Adongo, J., \& Stork, C. (2005). Factors Influencing the Financial Sustainability of Selected Microfinance Institutions in Namibia. The Namibian Economic Policy Research Unit (NEPRU).

Afriyie, H. O., \& Akotey, J. O. (2013).Credit Risk Management and Profitability of Rural Banks in the Brong Ahafo Region of Ghana. European Journal of Business and Management, 5(24), 18-21.

Ajai, N., \&Fissha, A. (2010). Rural Banking: The Case of Rural and Community Banks 
inGhana. Agriculture and Rural Development Discussion Paper 48 (pp. 2-5).

Antwi, F., \& Apau, E. V. (2015). Financial Performance of Rural and Community Banks (RCBs) in Ghana. The International Journal of Business \& Management, 3(2), 113-115.

ARB Apex Bank. (2012, September). 3rd Quarter Report on the Performance of Rural and Community Banks (RCBs). Geberal Circular No. 16/12. Efficiency Monitoring Unit (EMU).

Armendáriz, B., \& Morduch, J. (2007).The Economics of Microfinance. London: The MIT Press Cambridge.

Asiama, J. P., \& Osei, V. (2007). Micro finance in Ghana: An Overview. Research Department Working Paper. Bank of Ghana.

Asiedu-Mante, E. (2011). Rural Banking in Ghana. Combert Impressions Ltd.

Awunyo-Vitor, D. (2012). Determinants of loan repayment default among farmers in Ghana. Journal of Development and Agricultural Economics, 4(13), 339-345.

Babbie, E. (1995). The Practice of Social Research. California: Wadsworth Publishing.

Brake, D. (2000). Financial Market Analysis. London: Addison Wesley.

Chelagat, K. N. (2012). Determinants of Loan Defaults by Small and Medium Enterprises among Commercial Banks in Kenya. Master's Dissertation (pp. 5-56.), University of Nairobi, Kenya.

Chetan, T. (2007). Are Financial and Social Objectives Mutually Exclusive? The Experience of AMK, Cambodia. Small Enterprise Development, 18(1), 65-78.

Churchill, G. A., \& Iacobucci, D. (2005) Marketing Research: Methodological Foundations (9th ed.). USA: Homson South-Western.

Donkor, J. (2013). Relationship between Savings and Credit in Rural Banks with Specific Reference to Ghana. International Journal of Business and Social Science, 4(8), 234-250.

Ghana Statistical Service (GSS). (2018). Ghana Living Standards Survey Round 7: Poverty Trends in Ghana 2005-2017. Retrieved from http://www.statsghana.gov.gh/docfiles/publications/GLSS7/Poverty\%20Profile\%20Report_2 005\%20-\%202017.pdf

Ghana Statistical Service (GSS). (2014, October). District Analytical Report: 2010 Population and Housing Census. Ejisu-Juaben Municipal.

Ghana Statistical Service (GSS). (2006, October).Ghana Living Standards Survey: Report of the Fourth Round. Accra.

Hair, J. F., Black, W. C., Babin, B. J., Anderson, R. E., \& Tatham, R. L. (2006). Multivariate Data Analysis (6th ed.). New Jersey: Pearson Education.

Honohan, P. (2004). Financial sector policy and the poor: Selected findings and issues. Washington DC: The World Bank. 
Honohan, P. (2004). Financial sector policy and the poor: Selected.

IFAD (International Fund for Agricultural Development). (2008). The Republic of Ghana Rural and Agricultural Finance Program, IFAD (RAFiP). Rome.

Khandker, S. R., \& Khalily, M. A. B. (1995). Grameen Bank: performance and sustainability. Washington DC, World Bank Publications.

Littlefield, E., Murdoch, J., \& Hashemi, S. (2003). Is microfinance an effective strategy to reach the millennium development goals?

Local Government Training and Research Institute, Society for Development Studies. (2016). Retrieved April 23, 2016, from http://www.logotri.net/

Logotri. (2006). Building Sustainable Microfinance System: A Growth Catalyst for the Poor.

Mills, E. F. E. A., \& Amowine, N. (2013). The Rural Bank Profitability Nexus: Evidence from Ghana. International Journal or Application in Engineering and Management, 2(4), 5-11.

Nair, A., \& Fissha, A. (2010). Rural Banking: The Case of Rural and Community Banks in Ghana. Agriculture and Rural Development Discussion Paper 48, the World Bank, Washington, D.C.

Navajas, S., Schreiner, M., Meyer, R. L., Gonzalez-Vega, C., \& Rodriguez-Meza, J. (2000). Microcredit and the Poorest of the Poor: Theory and Evidence from Bolivia. World Development, 28(2), 333-346.

Nyamsogoro, G. D. (2010). Financial Sustainability of Rural Microfinance Institutions (MFIs) in Tanzania. A thesis submitted in partial fulfillment of the requirements of the University of Greenwich for the Degree of Doctor of Philosophy Greenwich Academic Literature Archive (GALA) - the University of Greenwich open access repository.

Owusu-Antwi, G., Antwi, J., \& Crabbe, M. (2014). The Performance of Banks in Ghana: The Ages Have Past Anything Recommended for the Future. International Review of Management and Business Research, 3(2), 93-101.

Rai, A., \& Anil, K. (2011). Financial Performance of Microfinance Institutions: Bank VsNbfc. International Journal of Management and Strategy, 2(2), 1-7.

Schreiner, M. (2000). Ways Donors Can Help the Evolution of Sustainable Microfinance Organizations. Savings and Development, 24(4), 423-437.

Schreiner, M. (2001). Seven Aspects of Loan Size. Journal of Microfinance, 3(2), 18-24.

Sebe-Yeboah, G., \& Mensah, C. (2014). A Critical Analysis of Financial Performance of Agricultural Development Bank (ADB, Ghana). European Journal of Accounting Auditing and Finance Research, 2(1), 1-23.

Shankar, S. (2007). Transaction Costs in Group Microcredit in India. Management Decision Journal, 45(8), 1331-1342. 


\section{Macrothink \\ International Journal of Accounting and Financial Reporting ISSN 2162-3082 2019, Vol. 9, No. 1}

Woller, G., Dunford, C., \& Woodworth, W. (1999).Where to microfinance. International Journal of Economic Development, 1, 29-64.

World Bank. (2010). The case of Rural and Commercial Banking in Ghana. Agricultural and Rural Development Discussion Paper No. 48. Washington, DC. Retrieved from www.worldbank.org

\section{Copyright Disclaimer}

Copyright for this article is retained by the author(s), with first publication rights granted to the journal.

This is an open-access article distributed under the terms and conditions of the Creative Commons Attribution license (http://creativecommons.org/licenses/by/4.0/) 